\title{
MEDIA SOSIAL SEBAGAI SARANA INFORMASI DAN PROMOSI PARIWISATA BAGI GENERASI Z DI KABUPATEN GARUT
}

\author{
E. Trihayuningtyas ${ }^{1}$ \\ Sekolah Tinggi Pariwisata NHI Bandung \\ Tyas_ent@yahoo.com \\ W.Wulandari ${ }^{2}$ \\ Sekolah Tinggi Pariwisata NHI Bandung \\ w.wulandari@stp-bandung.ac.id \\ Y. Adriani, I.A.M.P ${ }^{3}$ \\ Sekolah Tinggi Pariwisata NHI Bandung \\ Yaa_violet@yahoo.com \\ Sarasvati ${ }^{4}$ \\ Sekolah Tinggi Pariwisata NHI Bandung \\ paramitasaras@gmail.com
}

\begin{abstract}
ABSTRAK
Tujuan dari penelitian ini adalah untuk mengetahui sejauh mana media sosial dapat dijadikan sebagai sarana informasi khususnya di Kabupaten Garut.Penelitian ini juga menganalisa media sosial apakah yang menjadi pilihan bagi wisatawan generasi $\mathrm{Z}$ yang merupakan pasar potensial dan sedang berkembang.Penelitian ini menyasar pada wisatawan yang berada pada kategori generasi $\mathrm{Z}$ dimana rentangan usia 17 sampai 28 tahun dan sudah memiliki pengalaman berkunjung ke Kabupaten Garut dengan melakukan penyebaran kuesioner secara online. Observasi lapangan dan wawancara juga dilakukan pada penelitian ini untuk melihat kondisi aktual dari perkembangan wisata di Kabupaten Garut khususnya yang berkaitan dengan penyediaan sarana informasi dan promosi.Hasil analisis yang dilakukan dengan menggunakan SPSS 21 menunjukkan jika media sosial merupakan sarana informasi dan promosi yang sangat sesuai untuk wisatawan generasi $\mathrm{Z}$ di bidang pariwisata dan Instagram merupakan pilihan yang utama.Oleh karena itu pemerintah daerah Kabupaten Garut khususnya Dinas Pariwisata dan Kebudayaan Kabupaten Garut sebagai pembuat kebijakan harus dapat merangkul pasar wisatawan generasi $Z$ dengan cara mempertimbangkan habitual mereka terhadap penggunaan media sosial.
\end{abstract}

Kata Kunci: Sosial Media, Pariwisata, Generasi Z 


\title{
SOCIAL MEDIA AS A MEAN OF TOURISM INFORMATION AND PROMOTION FOR Z GENERATION IN GARUT REGENCY
}

\begin{abstract}
The purpose of this research is to determine the influence ofsosial media to provision of information and promotion for tourism, especially in Garut District. This research also analyzes the choices of Generation $\mathrm{Z}$ in media sosial. This research is aimed at tourists who are in the category of $Z$ generation where the age range of 17 to 28 years and already has experience visiting the Garut regency by distributing questionnaires online. Observations and interviews were also conducted in this research to see the actual condition of tourism development in Garut District, especially related to the provision of information and promotion. Results of analysis conducted by using SPSS 21 indicatesthat media sosial is a choice for generation $\mathrm{Z}$ in provision for their needs and the Instagram has become the main choice. Therefore the local government of Garut Regency, especially the Department of Tourism and Culture of Garut regency as policy makers should be able to embrace the Z-generation tourist market by considering their habitual use of sosial media.
\end{abstract}

Keywords : Media Sosial, Tourism, Generation Z

\section{PENDAHULUAN}

Media sosial merupakan media digital atau internet yang memiliki potensi sebagai media pemberdayaan masyarakat. Pemberdayaan dapat menjadikan media sosial sebagai media promosi produk atau jasa yang akan dipasarkan, salah satunya produk pariwisata. Sedikit banyak, media sosial telah menggeser kecenderungan konsumsi pariwisata.Dahulu mungkin pariwisata hanya menjadi kebutuhan "tersier", namun sekarang pariwisata telah sedikit bergeser untuk sebagian besar masyarakat menjadi suatu kebutuhan sekunder bahkan beberapa kalangan sudah menjadikan sebagai kebutuhan primer.Sebelumnya sudah banyak cara yang dipakai dalam memajukan pariwisata, misalnya menggunakan promosi di TV, iklan, brosur, dan pameran. Promosi pariwisata melalui media sosial bisa dikatakan sebagai cara yang tergolong baru dan berdampak besar juga dalam mendorong mobilitas wisatawan (Fatanti \& Suyadnya, 2015). Dengan menggunakan media sosial wisatawan atau konsumen dapat membagikan pengalaman mereka serta bisa juga digunakan sebagai sumber dalam pencarian informasi mengenai destinasi wisata (Gohil, 2015). 
Dalam konsep besar pemasaran, khususnya produk pariwisata, media sosial menduduki sebagai faktor determinan dalam bauran pemasaran wisata, yakni sub-bauran promosi. Hal ini beralasan pada media sosial yang memiliki muatan komunikasi dan persuasi produk kepada calon wisatawan, seperti apa yang terdapat pada pernyataan berikut: "Promotion means activities that communicate the merits of the product and persuade target customers to buy it". (Kotler dan Armstrong, 2012:76), pengertian tersebut dapat diartikan bahwa promosi merupakan aktivitas untuk mengkomunikasikan produk dan membujuk konsumen untuk membeli produk yang ditawarkan, seperti halnya media sosial.

Media sosial penggunaannya dirasa mudah, hemat biaya dan efektif dalam pemasaran pariwisata bagi suatu daerah, maka hal tersebut yang membuat media sosial semakin diminati untuk sarana komunikasi dan promosi (Gohil, 2015). Selain itu penggunaan media sosial juga dapat dimanfaatkan untuk mengekspresikan pengalaman melalui foto maupun video bisa dalam bentuk komentar sebagai bentuk interaksi tidak hanya dengan keluarga tetapi juga bisa dengan orang lain. (Martínez, Berrozpe, \& Lasarte, 2014).

Banyaknya masyarakat yang mulai melakukan pemesanan daring dapat membuat industri pariwisata lebih makmur dan lebih efisisen dalam menjalankan bisnis maupun memajukan destinasi pariwisata mereka.Teknologi daring dapat dimanfaatkan sebagai sarana untuk berkomunikasi, menginformasikan, bernegosiasi, dan mengurangi kesenjangan komunikasi tanpa terhambat oleh jarak dan waktu yang dapat menciptakan struktur baru untuk pengembangan dan pengoperasian pariwisata (Hasan, 2015). Dari fenomena tersebut menunjukan bahwa memang cara tercepat dan yang dapat diandalkan bagi wisatawan untuk mencapai pendirian pariwisata adalah dengan melalui internet.

Roda pergerakan pariwisata di Indonesia sangat besar peranannya berasal dari wisatawan nusantara atau domestic tourist. Seperti yang kita ketahui jumlah penduduk di Indonesia saat ini mencapai 261,1 juta (updated data BPS, 2016) dan sebanyak 42,45 juta penduduk Indonesia atau 16,26 \% dari populasi merupakan generasi Z. Generasi Z menurut Badan Statistika Kanada merupakan generasi yang lahir mulai tahun 1993 sampai dengan tahun 2011. Generasi Z dianalogikan dengan angkatan usia yang sudah "melek" akan teknologi dalam hal ini selalu dihubungkan akan dunia maya atau internet. Keberadaaan internet di Indonesia dimulai pada tahun 1990, dan seperti yang ditulis dalam https://tirto.id/selamat-tinggal-generasi-milenial-selamat-datang-generasi-z-cnzX; diakses 10 Agustus 2017 bahwa baru pada tahun 1994 Indonet sebagai penyelenggara komersil jasa internet perdana hadir di Indonesia, sehingga dapat dikatakan bahwa generasi Z Indonesia adalah generasi yang lahir pada pertengahan tahun 1990-an sampai dengan pertengahan tahun 2000-an, dengan begitu rentangan usia generasi $Z$ di Indonesia berkisar antara 5 sampai dengan 27 tahun yang tertua. Generasi Z yang sangat akrab 
dengan dunia maya atau internet bahkan cenderung ketergantungan dalam melakukan banyak hal termasuk dalam hal pencarian informasi tentang pariwisata, dimana mereka menganggap bahwa pariwisata sudah menjadi kebutuhan psikologis mereka. Dengan tersedianya segala macam informasi tentang pariwisata dalam internet dirasakan oleh mereka mampu memberikan segala kebutuhan informasi destinasi wisata dan sarana penunjang kegiatan wisata yang akan mereka lakukan.

Pentingnya sektor wisata yang telah digambarkan diatas bagi pendapatan Negara, dan generasi $\mathrm{Z}$ sebagai konsumen wisata ataupun wisatawan potensial bagi pergerakan industry wisata di Indonesia, menuntut adanya peningkatan penyediaan informasi tentang kepariwisataan yang bersifat digital atau E-Tourism.E-Tourism yang telah dilakukan saat ini pada umumnya berupa sosial media dan itu dikelola secara sukarela dan perorangan. Sebagai imbas dari adanya digitalisasi informasi pariwisata sangat dirasakan oleh salah satu daerah di Jawa Barat yaitu Kabupaten Garut.

Kabupaten Garut merupakan salah satu kabupaten di Jawa Barat. Daerah ini dikenal sebagai daerah penyangga ibu kota karena letak geografisnya yang memiliki jarak tempuh paling dekat dengan Ibu Kota Provinsi Jawa Barat. Kabupaten Garut memiliki prioritas utama dalam pembangunan insustri pariwisata.Kabupaten Garut juga memiliki keindahan alam dengan beraneka ragam objek wisata yang dikenal dengan gurilaps (gunung, rimba, laut, pantai dan situ), beraneka ragam kesenian tradisional dan kebudayaan, adat istiadat setempat yang dapat dikemas menjadi komoditi pariwisata yang dapat dijual baik secara lokal, nasional dan secara internasional.Potensi wisata yang dimiliki Kabupaten Garut hendaknya dikomunikasikan dengan baik kepada wisatawan potensial yaitu Generasi Z dengan cara peningkatan E-Tourism.

Kabupaten Garut telah menjelma menjadi destinasi wisata primadona di mata wisatawan domestik yang berada pada lini generasi Z, ini disesuaikan dengan karakteristik wisatawan generasi Z yang menyukai akan hal berbau "eksistensi diri" salah satunya dengan cara mengunggah photo di media sosial. Kabupaten Garut mempunyai spot berfoto yang indah pada destinasi wisatanya sehingga dirasa mampu memenuhi hasrat para wisatawan generasi $\mathrm{Z}$ untuk menunjukan eksistensinya. Beragam media sosial digunakan oleh generasi Z seperti Facebook, Instagram, Twitter, ataupun Blog.

Adapun dalam penelitian ini media sosial yang ditelusuri lebih dikhususkan kepada media sosial Instagram (IG), dengan alasan bahwa portal Instagram sangat dekat dengan kehidupan sehari-hari Generasi Z. Pasalnya Instagram memiliki 5 peran dalam pembentukan kepribadian remaja. Pertama, Instagram berperan sebagai media informasi tentang orang-orang disekitar mereka.Kedua, Instagram berperan sebagai media pengembangan minat pribadi dan minat spiritual bagi remaja.Ketiga, Instagram berperan sebagai media untuk menghibur diri.Keempat, Instagram berperan sebagai media untuk mengungkapkan emosi bagi remaja.Kelima, Instagram berperan untuk membentuk citra diri yang baru bagi remaja. 
Berdasarkan rumusan masalah yang telah dipaparkan diatas, maka tujuan penelitian ini adalah :

1. Menghasilkan gambaran profil Generasi $\mathrm{Z}$ secara aktual di Kabupaten Garut.

2. Menghasilkan analisis mengenai tingkat keterdedahan, yakni sejauh mana perilaku Generasi Z secara umum maupun khususmenindaklanjuti media sosial (Instagram) sebagai sarana penyebaran informasi dan promosi produk pariwisata Kabupaten Garut.

3. Menghasilkan analisis mengenai tingkatefektivitas penyebaran informasi dan promosi di Kabupaten Garut.

\section{METODOLOGI}

\section{Jenis Penelitian}

Pendekatan yang digunakan dalam penelitian ini adalah pendekatan kuantitatif dan didukung dengan data kualitatif.Pendekatan kuantitatif digunakan dalam survei kepada responden.Menurut Singarimbun dan Effendi (2008), penelitian survei adalah penelitian yang mengambil sampel dari satu populasi dan menggunakan kuesioner sebagai alat pengumpulan data yang pokok.Pada data kualitatif dilakukan dengan wawancara mendalam dengan informan dan responden melalui telepon.Sumber pertama atau informan dalam penelitian yaitu pihak pemerintah Kabupaten Garut. Pengumpulan data primer juga diperoleh dari hasil kuesioner dari para responden Generasi Z yang menjadi pengikut atau followers akun-akun media sosial, khususnya Instagram yang terkait produk pariwisata Kabupaten Garut.

\section{Lokasi Penelitian}

Penelitian tentang Generasi Z dan Sosial Media ini akan dilakukan di Kabupaten Garut dan secara online. Pemilihan promosi produk pariwisata Kabupaten Garut sebagai objek penelitian dengan mempertimbangkan beberapa hal, meliputi:

a. Kabupaten Garut sebagai salah satu destinasi wisata skala regional, sekaligus sebagai salah satu dari 16 Destinasi Pariwisata Unggulan di Provinsi Jawa Barat.

b. Kabupaten Garut memiliki keindahan alam dengan beraneka ragam objek wisata yang dikenal dengan gurilaps (gunung, rimba, laut, pantai dan situ), beraneka ragam kesenian tradisional dan kebudayaan, adat istiadat setempat yang sesuai dengantren dan karakteristik 'New Tourism' (Venema, 2011) yakni:

1. Memperhatikan lingkungan dan keberlanjutan

2. Peningkatan pengalaman perjalanan

3. Lebih banyak permintaan \& berpengalaman 
4. Lebih banyak pemberitaan media (TV, Internet, Twitter)

5. Pengalaman lebih penting dari sekedar matahari

6. Produk baru \& metode distribusi baru

7. Usaha pariwisata lebih terintegrasi secara vertikal \& horizontal

8. Teknologi baru (Internet, Computer Reservation Systems, Database Marketing, Smart Phones, Sosial Media)

\section{Instrumen Penelitian}

Didalam penelitian ini data yang akan dianalisa berupa data lisan ataupun tulisan yang didapat dari respoden. Teknik pengumpulan data yang diterapkan dalam penelitian ini untuk lebih jelasnya dapat dipaparkan sebagai berikut :

a. Kuesioner

Penyebaran kuesioner digunakan untuk menemukenali tingkat keterdedahan dan tingkat efektivitas media sosial (Instagram) dalam penyediaan informasi dan promosi wisata, dilakukan secara langsung dan online.

b. Daftar pertanyaan (Wawancara)

Daftar pertanyaan diterapkan dalam penelitian ini untuk pengumpulan data sesi wawancara. Wawancara dilakukan kepadastakeholder pariwisata Kabupaten Garut yaitu pemerintah dalam hal ini diwakili oleh Dinas Pariwisata dan Kebudayaan Kabupaten Garut, swasta dalam penelitian ini diwakili oleh pelaku usaha pariwisata Kabupaten Garut (Picnic, Chocodot, Danau Dariza, dan Kolam Air Panas Papandayan), serta masyarakat yang diwakili oleh Yayasan Asgar Muda, Paguyuban Masyarakat Pasirwangi, dan Paguyuban Masyarakat Situ Bagendit.

\section{Teknik Penentuan Responden dan Informan}

Populasi dalam penelitian ini adalah Generasi Z, dengan rentang usia 10-24 tahun. Adapun responden dalam penelitian ini adalah Generasi $Z$ yang merupakan pengikut atau followers dari media sosial, khususnya Instagram (IG) terkait langsung maupun tidak langsung produk kepariwisataan di Kabupaten Garut, yakni sebagai berikut:

Tabel 1.

Portal Media Sosial

\begin{tabular}{|c|l|l|}
\hline NO & \multicolumn{1}{|c|}{ PORTAL MEDIA SOSIAL } & \multicolumn{1}{c|}{ NAMAAKUN } \\
\hline 1 & INSTAGRAM & @galerigarut \\
& & @jelajah_garut \\
& & @exploregarut \\
& & @exploregarutselatan \\
& & @infogarut
\end{tabular}




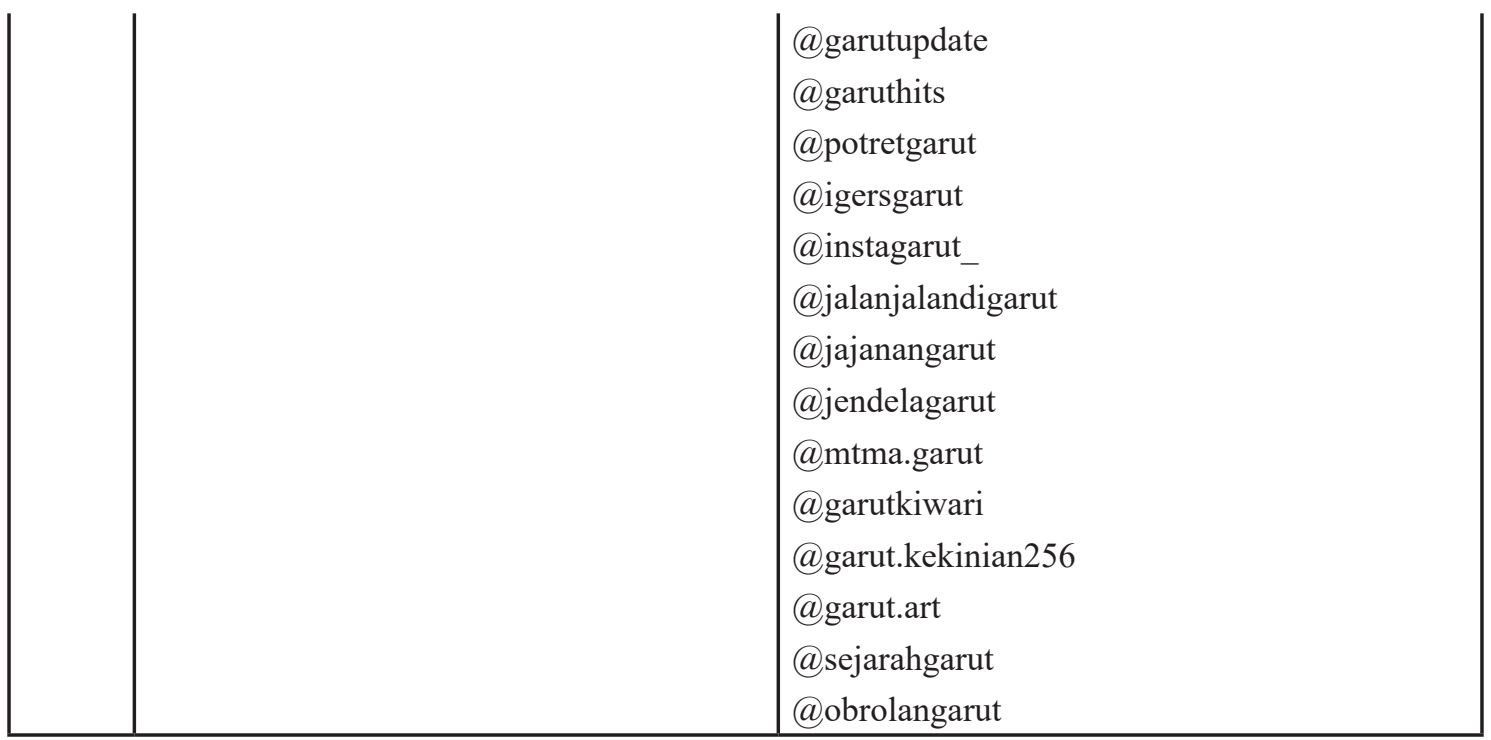

Sumber: Instagram, 2018

Responden yang diambil dalam penelitian ini adalah responden yang bersifat followers.

Metode pengambilan sampel yang digunakan dalam penelitian ini adalah nonprobability yaitu teknik sampling yang tidak memberikan kesempatan (peluang) pada setiap anggota populasi untuk dijadikan anggota sampel (Alma 2009).

\section{Teknik Pengolahan dan Analisis Data}

Pengolahan data dilakukan dengan menggunakan program Microsoft Excel 2007 dan Statistical Program for Sosial Sciences (SPSS 21) for windows.Sebelum kuesioner tersebut disebar, terlebih dahulu kuesioner diuji menggunakan uji validitas. Data kemudian dianalisis menggunakan Uji korelasi Rank Spearman. Uji korelasi Rank Spearman digunakan untuk mengetahui hubungan antara karakteristik responden (usia, tingkat pendidikan, tingkat pendapatan) dengan tingkat keterdedahan media sosial (frekuensi pesan, frekuensi feedback pesan, tingkat daya tarik pesan dan kejelasan dalam penyampaian pesan), dan tingkat keterdedahan media sosial dengan perspektif promosi pariwisata melalui media sosialdengan empat tahap AIDA.

\section{HASIL DAN PEMBAHASAN}

\section{A. Gambaran Aktual Profil Generasi Z}

Karakteristik generasi $\mathrm{Z}$ pengikut atau followers media sosial akun pariwisata Kabupaten Garut dapat dilihat dalam penelitian ini, yakni terdiri atas 5 variabel, yaitu: 1) Jenis Kelamin, 2) Usia, 3) Pendidikan Terakhir, 4) Jenis Pekerjaan, dan 5) Tingkat 
Pendapatan. Adapun karakteristik Generasi Z pengikut akun-akun Instagram produk pariwisata Kabupaten Garut dapat dilihat lebih lanjut pada tabel berikut :

Tabel 2.

Jumlah dan Prosentase Generasi Z terhadap Akun-Akun Pariwisata

Kabupaten Garut

\begin{tabular}{|c|c|c|c|c|c|}
\hline No & $\begin{array}{c}\text { Karakteristik Generasi } \\
\text { Z (followers) }\end{array}$ & Kategori & Jumlah & Prosentase & Rata-Rata \\
\hline 1 & USIA & $\begin{array}{l}\text { 10-14 Tahun } \\
\text { 15-19 Tahun } \\
\text { 20-24 Tahun }\end{array}$ & $\begin{array}{l}12 \\
20 \\
21\end{array}$ & $\begin{array}{l}22.6 \\
37.7 \\
39.6\end{array}$ & 22 \\
\hline 2 & JENIS KELAMIN & $\begin{array}{l}\text { Laki-Laki } \\
\text { Perempuan }\end{array}$ & $\begin{array}{l}14 \\
39\end{array}$ & $\begin{array}{l}26.4 \\
73.6\end{array}$ & \\
\hline 3 & $\begin{array}{l}\text { TINGKAT } \\
\text { PENDIDIKAN }\end{array}$ & $\begin{array}{l}\text { SMP/MTs/Sederajat } \\
\text { SMA/SMK/MAN/Sederajat } \\
\text { >Diploma }\end{array}$ & $\begin{array}{l}12 \\
26 \\
15\end{array}$ & $\begin{array}{c}22.6 \\
\mathbf{4 9 . 0 5} \\
28.3\end{array}$ & \\
\hline 4 & $\begin{array}{l}\text { JENIS } \\
\text { PEKERJAAN }\end{array}$ & $\begin{array}{l}\text { Pelajar } \\
\text { Mahasiswa }\end{array}$ & $\begin{array}{l}38 \\
15\end{array}$ & $\begin{array}{l}71.6 \\
28.3\end{array}$ & \\
\hline 5 & $\begin{array}{l}\text { TINGKAT } \\
\text { PENDAPATAN }\end{array}$ & $\begin{array}{l}<500 \mathrm{rb} \\
500 \mathrm{rb}-1 \mathrm{jt} \\
1 \mathrm{jt}-2 \mathrm{jt}\end{array}$ & $\begin{array}{l}19 \\
23 \\
11\end{array}$ & $\begin{array}{l}35.8 \\
\mathbf{4 3 . 4} \\
20.8\end{array}$ & \\
\hline \multicolumn{3}{|c|}{ TOTAL } & 53 & 100.0 & \\
\hline
\end{tabular}

Sumber : Data Olahan, 2018

Hasil penelitian menunjukan dari 53 orang responden diketahui bahwa rata-rata usia dalam penelitian ini yaitu 22 tahun dan diketahui umur yang paling muda yaitu berumur 12 tahun, sedangkan umur yang paling tua dari generasi $\mathrm{Z}$ pengguna media sosial akun pariwisata Kabupaten Garut adalah 24 tahun dapat terlihat pada tabel 2 diatas. Jika dilihat dari jumlah dan frekuensi tersebut, terlihat bahwa sebagian besar responden berada pada kategori usia 20-24 tahun. Hal tersebut disebabkan oleh sebagian besar generasi Z followers akun-akun instagram produk pariwisata Kabupaten Garut, kebanyakan berada pada kalangan pelajar atau mahasiswa ataupun sebagai fresh graduate.

\section{Jenis Kelamin}

Jenis kelamin merupakan sifat fisik responden yang tercatat dalam kartu identitas, yaitu laki-laki atau perempuan. Berdasarkan tabel 2 diperoleh data bahwa jenis kelamin Generasi $\mathrm{Z}$ yang menjadi responden mayoritas adalah perempuan sebanyak 39 responden (73.6\%) dan sebanyak 14 responden (26.4\%) adalah responden laki-laki. Hal ini dikarenakan, perempuan cenderung lebih senang bermain media sosial dibandingkan laki-laki. Hal ini didukung menurut Nrayung (2012) bahwa perempuan lebih menyukai dengan hal baru seperti dengan dunia maya sehingga kaum perempuan ini bisa menambah temannya meskipun hanya di dunia maya atau untuk berbelanja online. 


\section{Pendidikan Terakhir}

Berdasarkan kategori pendidikan, sebagian besar Generasi Z yang menjadi responden yaitu berjumlah 12 respondenatau dengan frekuensi memiliki pendidikan yaitu pada jenjang lulusan SMP/MTs/Sederajat sebesar 22.6\% dari keseluruhan total jumlah responden. Sementara itu untuk tingkat pendidikan lebih besar yakni jenjang SMA/SMK/ Sederajat berjumlah 26 responden sebesar $49.05 \%$, sedangkan jenjang yang lebih tinggi yakni Sarjana atau Diploma berjumlah 15 responden yakni sebesar 28.3\%. Menurut Sumarwan (2011), pendidikan individu dapat mempengaruhi proses keputusan dan pola konsumsi seseorang. Konsumen yang memiliki pendidikan lebih baik akan sangat responsif terhadap informasi, pendidikan juga mempengaruhi konsumen dalam pilihan produk maupun merek. Pendidikan yang berbeda akan menyebabkan selera konsumen juga berbeda.

\section{Jenis Pekerjaan}

Dapat terlihat pada tabel bahwa jenis pekerjaan Generasi Z yang menjadi respondenmayoritas adalah pelajar.Hal ini mengindikasikan bahwa pelajar memiliki banyak waktu luang sedikit lebih tinggi dibandingkan dengan profesi lainnya. Menurut Sumarwan (2011), pendidikan dan pekerjaan adalah dua karakteristik yang saling berhubungan. Pendidikan akan menentukan jenis pekerjaan yang dilakukan oleh seorang individu. Selanjutnya pekerjaan seseorang akan memengaruhi pendapatan yang diterimanya. Pendapatan dan pendidikan tersebut akan memengaruhi proses keputusan dan pola konsumsi seseorang.

\section{Tingkat Pendapatan}

Adapun pendapatan Generasi Z sebagai respondenpaling terbanyak berada di kategori pendapatan Rp 500.000 sampai Rp 1.000.000, sesuai dengan data sebelumnya yaitu Generasi Z yang menjadi respondendidominasi oleh kalangan pelajar.Menurut Sumarwan (2011), individu yang berpendidikan tinggi diasumsikan juga memiliki pendapatan yang tinggi. Pendapatan sangat penting bagi seorang calon wisatawan, dari pendapatan tersebut seorang calon wisatawan bisa membiayai kegiatan wisatanya. Jumlah pendapatan akan menggambarkan kemampuan melakukan kegiatan wisata seseorang/kelompok.

\section{B. Analisis Tingkat Keterdedahan Media Sosial}

Keterdedahan dalam penelitian ini ditelusuri melalui identifikasi terhadap perilaku umum dan khusus Generasi $Z$ terhadap produk pariwisata melalui media sosial Kabupaten Garut.Keterdedahan menurut Shore merujuk kepada Samsi (2005) adalah kegiatan mendengar, melihat, dan membaca, atau secara lebih umum memberikan sejumlah perhatian kepada suatu pesan yang disampaikan dengan menggunakan 
media sebagai perantara. Penelitian sebelumnya, menurut Shimp dalam Wulandari (2015) menyatakan bahwa untuk mengukur efektivitas internet yang dalam hal ini melalui media sosial dapat dilihat keterdedahan media sosial yang dapat dilihat dari frekuensi kunjungan pelanggan terhadap suatu akun media sosial produk, frekuensi pesan dan feedback, tingkat daya tarik pesan, lama kunjungan, serta jalan yang ditempuh untuk mencapai situs-situs media sosial tertentu. Penelitian ini dilakukan untuk mengukur sejauh mana pengaruhmedia sosialpariwisata Kabupaten Garut dilihat dari perilaku umum dan khususfollowers akun-akun pariwisata Kabupaten Garut. Tingkat keterdedahan dapatdirinci pada Tabel berikut:

Tabel 3.

Prosentase Penilaian Responden Terhadap Akun Instagram Produk Pariwisata Kab. Garut berdasarkan Aktivitas Promosi

\begin{tabular}{clccc}
\hline \multirow{2}{*}{ No } & \multirow{2}{*}{ Keterdedahan } & \multicolumn{3}{c}{ Penilaian Responden } \\
\cline { 3 - 5 } & & Rendah & Sedang & Tinggi \\
1 & Frekuensi Pesan & 3.8 & 18.9 & $\mathbf{7 7 . 4}$ \\
2 & Frekuensi Feedback Pesan & 7.5 & 35.8 & $\mathbf{5 6 . 6}$ \\
3 & Tingkat Daya Tarik Pesan & 1.9 & 7.5 & $\mathbf{9 0 . 6}$ \\
4 & Kejelasan dalam Penyampaian Pesan & 1.9 & 37.7 & $\mathbf{6 0 . 4}$ \\
\hline
\end{tabular}

Sumber : Data Olahan, 2018

Berdasarkan Tabel 3 diatas pada frekuensi pesan yang mendominasi berada pada kategori tinggi sebanyak $77.4 \%$ responden.Pada variabel frekuensi feedback pesan yang mendominasi berada pada kategori tinggi sebanyak $56.6 \%$ responden. Selanjutnya tingkat daya tarik pesan sebanyak $90.6 \%$ responden mendominasi pada kategori tinggi. Variabel kejelasan dalam penyampaian pesan, sebanyak $60.4 \%$ dengan kategori tinggi. Berdasarkan hasil penilaian pada Tabel 3 tersebut terlihat bahwa aktivitas promosi akunakun instagram pariwisata Kabupaten Garut tergolong tinggi pada semua variabel.

\section{Frekuensi Pesan}

Frekuensi pesan ini meliputi intensitas admin instagram dalam memberikan informasi mengenai produk pariwisata Kabupaten Garut yang di-posting setiap hari melalui foto/video. Pengukuran frekuensi pesan dilihat melalui beberapa indikator, yang bisa dijelaskan pada tabel berikut :

Tabel 4.

Prosentase Penilaian Responden Terhadap AkunInstagram

Produk Pariwisata Kab. Garut denganIndikator Frekuensi Pesan

\begin{tabular}{cccccc}
\hline No & Indikator & $\begin{array}{r}\text { Tidak } \\
\text { Pernah }\end{array}$ & Jarang & Sering & Selalu \\
\hline 1 & $\begin{array}{l}\text { Kemunculan foto atau video } \\
\text { di timeline setiap hari }\end{array}$ & 3.8 & 18,9 & $\mathbf{5 8 , 5}$ & 18,9 \\
\hline
\end{tabular}




\begin{tabular}{|c|c|c|c|c|c|}
\hline 2 & $\begin{array}{l}\text { Kemunculan foto atau video } \\
\text { menyampaikan informasi } \\
\text { produk setiap hari }\end{array}$ & 3.8 & 9,4 & 47,2 & 39,6 \\
\hline 3 & $\begin{array}{l}\text { Kemunculan foto atau video } \\
\text { menyampaikan informasi } \\
\text { promosi produk setiap hari }\end{array}$ & 3.8 & 11,3 & 28,3 & 56,6 \\
\hline 4 & $\begin{array}{l}\text { Kemunculan foto atau video } \\
\text { untuk menyapa followers } \\
\text { setiap hari }\end{array}$ & 3.8 & 26,4 & 43,4 & 26,4 \\
\hline
\end{tabular}

Sumber : Data Olahan, 2018

Berdasarkan tabel 4 kemunculan foto atau video di timeline setiap hari sebanyak $58.5 \%$ responden memilih kategori sering dengan frekuensi lebih besar dari kategori lainnya. Akun instagram pariwisata Kabupaten Garuttergolong rutin memposting foto atau video untuk sekedar menyapa, menyampaikan informasi produk atau tentang informasi promosi penjualan.Hal ini terlihat bahwa pada kemunculan foto atau videomengenai informasi produk menjawab sering sebanyak $47.2 \%$ responden. Pada informasi promosi penjualan sebanyak $56.6 \%$ responden menjawab selalu, bahwa Akunakun instagram pariwisata Kabupaten Garut memberikan informasi mengenai promosi produk pariwisatanya baik yang berbasis alam, budaya maupun buatan. Pada indikator lainnya adalah postingan yang berisi mengenai foto atau video untuk menyapa followers, sebanyak $43.4 \%$ responden berpendapat sering membaca atau sekedar melihat postingan sebagai bentuk sapaan admin instagram kepada para followers baik itu pada pagi hari, siang hari atau malam hari.

\section{Frekuensi Feedback Pesan}

Feedback pesan terhadap Generasi $\mathrm{Z}$ diukur melalui seringnya admin instagram memberi respon terhadap foto atau video yang di-tag oleh followers, admin instagram membalas komen yang dikirimkan dalam caption, dan kecepatan admin dalam membalas comment tersebut dalam jangka waktu segera yaitu kurang dari 24 jam. Penjelasan lebih lanjut dapat dilihat di Tabel berikut:

Tabel 5.

Prosentase Penilaian Responden Terhadap Akun Instagram Produk Pariwisata Kab. Garut dengan Indikator Feedback Pesan

\begin{tabular}{clcccc}
\hline No & \multicolumn{1}{c}{ Indikator } & Tidak Pernah & Jarang & Sering & Selalu \\
\hline \multicolumn{1}{c}{$\begin{array}{l}\text { Admin memberi respon } \\
\text { terhadap foto atau video yang } \\
\text { di tag }\end{array}$} & 7.5 & $\mathbf{3 2 . 1}$ & $\mathbf{3 2 . 1}$ & 28.3 \\
2 & $\begin{array}{l}\text { Admin membalas komen yang } \\
\text { dikirimkan dalam caption }\end{array}$ & 3.8 & 28.3 & $\mathbf{3 7 . 7}$ & 30.2
\end{tabular}




\begin{tabular}{|c|c|c|c|c|c|}
\hline 3 & $\begin{array}{l}\text { Admin membalas comment } \\
\text { dengan jangka waktu }<24 \text { jam }\end{array}$ & 5.7 & 34.0 & 34.0 & 26.4 \\
\hline
\end{tabular}

Sumber : Data Olahan, 2018

Dari uraian Tabel 5 di atas, dapat dilihat bahwa frekuensi feedback pesan pada indikator admin memberi respon terhadap foto atau video yang di-tag.Sebanyak 32.1 $\%$ responden menyatakan sering terhadap pernyataan admin memberi respon terhadap foto atau video yang di-tag.Membalas sebuah foto atau video yang di-tag dari followers dengan caramemberikan like atau komen pada postingan yang di-tag merupakan salah satu cara untuk berkomunikasi satu sama lain antara followers.

Indikator berikutnya yaitu admin instagram membalas komen yang dikirimkan dalam caption dan membalas comment yang masuk dengan jangka waktu segera yaitu kurang dari 24 jam. Sebanyak $37.7 \%$ menjawab sering bahwa admin instagram membalas komen yang dikirimkan dalam caption, sedangkan pada kecepatan admin instagram membalas comment sebanyak $34.0 \%$. Membalas comment merupakan bentuk feedback atau timbal balik yang dilakukan antara admin dengan penerima pesan yaitu followers, dalam hal ini Generasi Z.

\section{Tingkat Daya Tarik Pesan}

Daya tarik pesan merupakan salah satu aspek dari aktivitas promosi produk pariwisata yang memiliki peranan untuk menarik perhatian followers, dalam hal ini Generasi Zsebagai salah satu penentu dari keberhasilan suatu aktivitas promosi.Daya tarik pesan promosi dan informasi produk wisata bagi Generasi $\mathrm{Z}$ dapat diukur melalui lima indikator yang meliputi profile picture yang menarik, kualitas foto atau video dengan jelas, desain foto atau video secara menarik, caption menarik, dan dengan hashtag yang menarik yang memudahkan pencarian.Berikut adalah Tabel yang menyajikan data jumlah dan prosentase penilaian responden berdasarkan indikator daya tarik pesan akun-akun produk pariwisata Kabupaten Garut.

Tabel 6.

Prosentase Penilaian Responden Terhadap Akun Instagram Produk Pariwisata Kab. Garut dengan Indikator Daya Tarik Pesan

\begin{tabular}{cccccc}
\hline No & Indikator & $\begin{array}{c}\text { Sangat Tidak } \\
\text { Setuju }\end{array}$ & Tidak Setuju & Setuju & $\begin{array}{c}\text { Sangat } \\
\text { Setuju }\end{array}$ \\
\hline 1 & $\begin{array}{l}\text { Kualitas Foto dan Video } \\
\text { Jelas }\end{array}$ & 1.9 & 3.8 & 43.4 & $\mathbf{5 0 . 9}$ \\
\hline
\end{tabular}




\begin{tabular}{|c|c|c|c|c|c|}
\hline 2 & $\begin{array}{l}\text { Postingan Foto menarik } \\
\text { (Memiliki latar alam indah } \\
\text { untuk selfie/wefie) }\end{array}$ & 0 & 5.7 & 32.1 & 62.3 \\
\hline 3 & $\begin{array}{l}\text { Desain foto atau video } \\
\text { menarik (Konsep editing } \\
\text { kekinian/spektrum warna } \\
\text { menarik) }\end{array}$ & 1.9 & 1.9 & 47.2 & 49.1 \\
\hline 4 & Caption menarik & 1.9 & 3.8 & 54.7 & 39.6 \\
\hline 5 & $\begin{array}{l}\text { Tagar/Hashtag menarik dan } \\
\text { memudahkan pencarian }\end{array}$ & 1.9 & 3.8 & 41.5 & 52.8 \\
\hline
\end{tabular}

Sumber : Data Olahan, 2018

Berdasarkan Tabel 6 diatas beberapa pertanyaankuesioner online memiliki respon jawaban dari followers, khususnya Generasi $\mathrm{Z}$ terhadap akun-akun instagram produk pariwisata Kabupaten Garut sebagai responden menggambarkan bahwa indikator yang paling menjadi daya tarik pesan adalah postingan foto dan video menarik, terlebih spesifik memiliki latar alam yang indah untuk selfie maupun wefie. Hal tersebut dibuktikan oleh seluruh responden yang berjumlah $62.3 \%$ responden menilai sangat setuju bahwa postingan foto atau video latar alam yang indah untuk foto probadi (selfie) atau foto bersama (wefie) lebih baik dibandingkan dengan indikator daya tarik pesan lainnya.

\section{Gambar 1.}

Salah Satu Foto dalam Akun Instagram @galerigarut yang dianggap

Responden Memiliki Latar Indah untuk Aktivitas Selfie

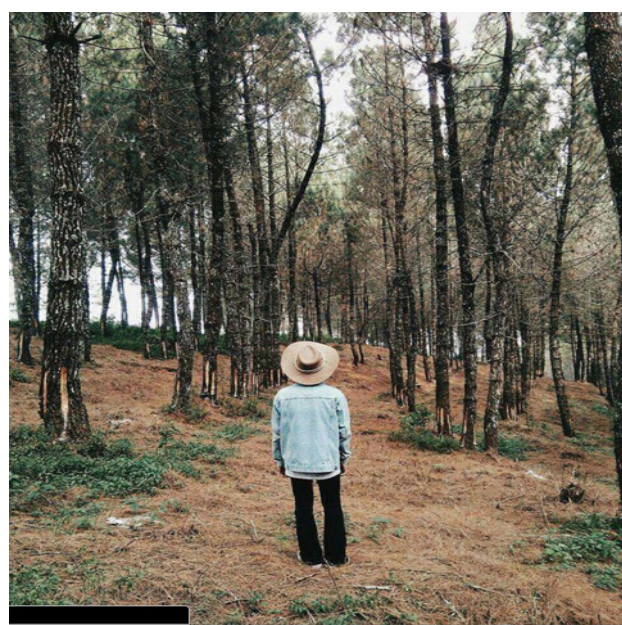

(2) galerigarut_. Ikuti

Kamojang Pangkalan Pateungteu...

galerigarut_\#galerigarut__Photo today by $@$ maikalan_Taken at Pangkalan
Pateungteung, Kamojang - Carut.

〜Share Your Moment With Us i Share Your Moment With Us_
is @galerigarut_\& \#galerigarut_ rymunawaroh Eumhh

fauzyannaufal siappp @maikalan_ citak_cute Dimananya kamojang ya?

Sumber : Instagram, 2018

Dari gambar 1 tersebut dapat diketahui bahwa Selfie menjadi hal yang lebih disukai karena followerslebih tertarik dengan promosi produk pariwisata yang bersifat visual dibandingkan dengan sebuah kata-kata atau kalimat.Menurut Salamoon (2013) instagram merupakan sebuah aplikasi yang memang khusus dalam berbagi foto yang menjadikan sebuah spesifikasi pada media sosial instagram.Latar alam indah menjadi faktor daya tarik pesan utama bagi kalangan Generasi Z.Selain postingan foto atau video latar alam 
yang indah, indikator daya tarik pesan produk pariwisata yang mendapat perhatian para followersadalah caption yang di-posting secara menarik. Terlihat sebanyak 54.7 $\%$ menjawab setuju bahwa caption yang dibuat menggunakan bahasa yang menarik. Indikator selanjutnya adalah hashtag yang dibuat secara menarik dan memudahkan pencarian.

\section{Gambar 2.}

Salah Satu Caption dan Hashtag dalam Akun Instagram @jelajah_garut yang dianggap Responden Menarik dan Memudahkan Pencarian

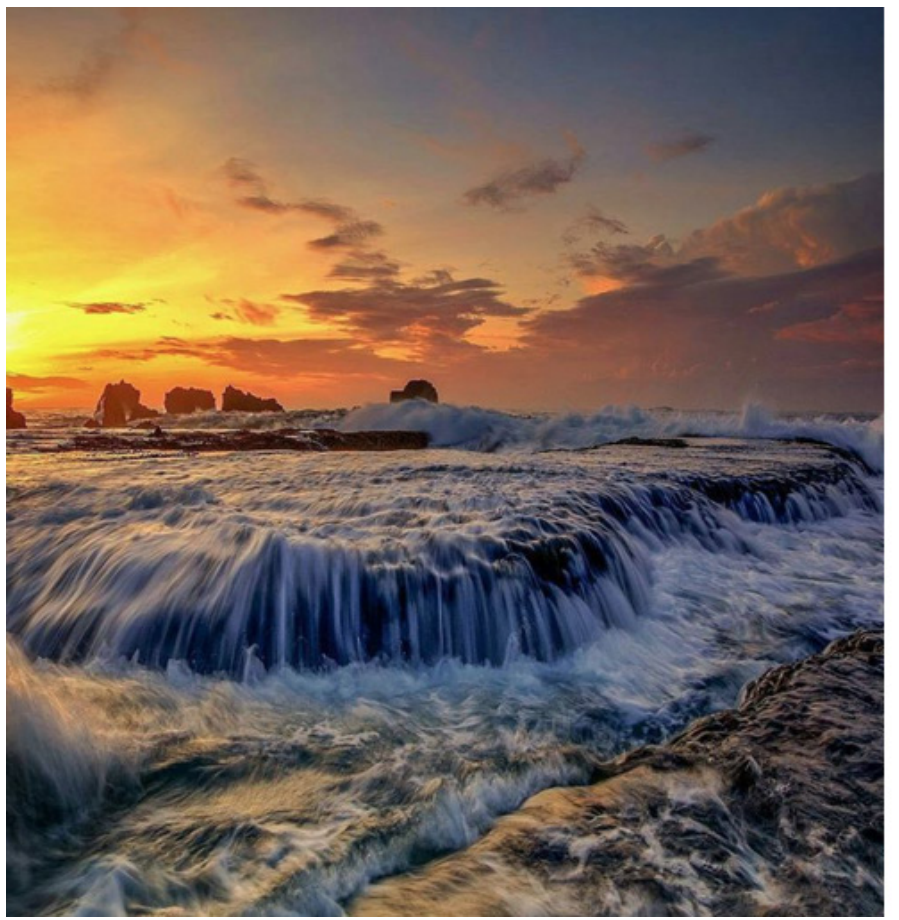

fg jelajah_garut • Ikuti

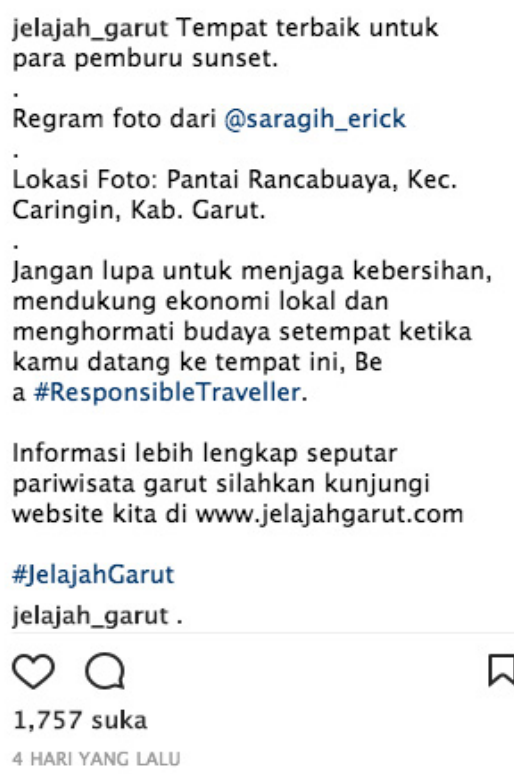

Sumber : Instagram, 2018

Indikator lainnya seperti kualitas foto dan video sebanyak $50.9 \%$ responden menjawab sangat setuju.Kualitas foto atau video yang baik dapat meningkatkan ketertarikan lebih kepada suatu informasi yang disampaikan.

Indikator selanjutnya adalah desain foto atau video dibuat menarik. Sebanyak 49.1\% responden menyatakan sangat setuju bahwa desain yang di-posting dibuat menarik.

\section{Kejelasan Dalam Penyampaian Pesan}

Kejelasan dalam penyampaian pesan merupakan kesesuaian pesan yang disampaikan melalui media dengan keadaan yang sebenarnya dan disampaikan secara jelas. Keterangan lebih rinci dapat dilihat pada Tabel brikut : 
Tabel 7.

Prosentase Penilaian Responden terhadap Akun Instagram Produk Pariwisata Kab. Garut dengan Kejelasan dalam Penyampaian Pesan

\begin{tabular}{clcccc}
\hline No & \multicolumn{1}{c}{ Indikator } & $\begin{array}{c}\text { Sangat Tidak } \\
\text { Setuju }\end{array}$ & Tidak Setuju & Setuju & $\begin{array}{c}\text { Sangat } \\
\text { Setuju }\end{array}$ \\
\hline 1 & $\begin{array}{l}\text { Pencantuman informasi } \\
\text { produk pariwisata }\end{array}$ & 1.9 & 1.9 & 35.8 & $\mathbf{6 0 . 4}$ \\
2 & $\begin{array}{l}\text { Kelengkapan informasi dan } \\
\text { kontak }\end{array}$ & 11.3 & $\mathbf{3 9 . 6}$ & 26.4 & 22.6 \\
\hline
\end{tabular}

Sumber : Data Olahan, 2018

Berdasarkan Tabel 7 diatas sebanyak $60.4 \%$ responden menilai sangat setuju bahwa akun-akun instagram produk pariwisata Kabupaten Garut mencantumkan seputar informasi produk pariwisata di instagram. Indikator selanjutnya adalah informasi mengenai contact dengan hasil sebanyak $39.4 \%$ responden menilai tidak setuju bahwa informasi dan kontak yang dapat dihubungi tersebut sudah cukup lengkap.

\section{Tingkat Efektivitas Penyebaran Media Informasi dan Promosi}

Promosi merupakan salah satu titik fokus pelaku bisnis untuk memperkenalkan produk dan dipasarkan kepada calon konsumen.Menurut (Wulandari 2015) bahwa suatu promosi dikatakan efektif jika pesan yang disampaikan mudah dicerna dan dimengerti oleh masyarakat serta mengandung informasi yang benar sehingga masyarakat (konsumen) dapat mencermati informasi tersebut dengan sudut pandang yang benar.Pengukuran efektivitas promosi produk pariwisata Kabupaten Garut melalui media sosial instagram khususnya pada kelompok Generasi Z dilakukan dengan melihat keempat tahapan AIDA (Attention, Interest, Desire, dan Action). Penjelasan lebih rinci dapat dilihat pada Tabel berikut :

Tabel 8.

Jumlah dan Prosentase Generasi Z terhadap Akun Instagram Produk Pariwisata Kab. Garut

\begin{tabular}{clcc}
\hline No & Efektivitas Instagram Media Promosi Pariwisata & Jumlah & Prosentase \\
\hline 1 & Attention (Perhatian) & 53 & $100 \%$ \\
2 & Interest (Ketertarikan) & 49 & 92.45 \\
3 & Desire (Keinginan) & 46 & 86.79 \\
4 & Action (Tindakan) & 45 & 84.9 \\
\hline
\end{tabular}

Sumber : Data Olahan, 2018

Berdasarkan Tabel8 diatas terlihat bahwa tidak semua Generasi Z yang menjadi followersmencapai tahap action (tindakan) sedangkan pada tahap attention (perhatian) seluruh responden mencapai tahap tersebut yaitu sebanyak 53 followers atau (100\%). Hal ini karena followersatau responden yang pernah melihat postingan atau membaca caption 
yang ada di akun-akuninstagramproduk pariwisata Kabupaten Garut. Selanjutnya pada tahap interest terjadi pengurangan yang terbanyak yaitu jumlah followers dari tahap attention sebanyak 4 followers, pada tahap interest ke tahap desire terjadi pengurangan sebanyak 3 followers, dan pada tahap terakhir yaitu desire menuju tahap action hanya terjadi pengurangan paling sedikit yaitu hanya 1 followers .Jadi dari tahap attention menuju tahap action terjadi pengurangan jumlah followers yaitu 8 orang. Keempat tahapan tersebut dibagi menjadi tiga kategori yaitu rendah, sedang, dan tinggi. Penjelasan rinci terkait kategori tersebut dapat dilihat pada Tabel berikut :

Tabel 9.

Prosentase Penilaian Generasi Z terhadap Akun-Akun Instagram Produk Pariwisata Kabupaten Garut berdasarkan Efektivitas

Media Promosi

\begin{tabular}{clccc}
\hline \multirow{2}{*}{ No } & \multirow{2}{*}{ Efektivitas Promosi } & \multicolumn{3}{c}{ Penilaian Responden } \\
\cline { 3 - 5 } & & Rendah & Sedang & Tinggi \\
1 & Attention (Perhatian) & 1.9 & 26.4 & 71.7 \\
2 & Interest (Ketertarikan) & 2.0 & 28.6 & 69.4 \\
3 & Desire (Keinginan) & 2.2 & 26.1 & 71.7 \\
4 & Action (Tindakan) & 2.2 & 13.3 & 84.5 \\
\hline
\end{tabular}

Sumber : Data Olahan, 2018

Berdasarkan Tabe19 diatas penilaian Generasi Z sebagai responden terkait efektivitas promosi pada tahap attention dapat dilihat sebanyak $71.7 \%$ responden menilai bahwa promosi melalui instagram dalam menarik perhatian Generasi Z sudah baik. Tahap interest menunjukkan hasil yang tinggi sebanyak $69.4 \%$ responden menilai bahwa promosi produk pariwisata melalui instagram dalam menimbulkan ketertarikan Generasi Zsudah baik.Hal serupa juga terjadi pada tahap desire, sebanyak $71.7 \%$ responden menilai bahwa promosi melalui instagram dalam menumbuhkan keinginan melakukan kegiatan wisata sudah baik. Pada tahap terakhir yaitu action menunjukkan hasil yang tinggi sebanyak $84.5 \%$ responden menilai promosi produk pariwisata melalui instagram mampu menimbulkan tindakan followersuntuk melakukan tindakan pembelian, merekomendasikan kepada teman atau kerabat.

\section{Attention (Perhatian)}

Attention merupakan bentuk perhatian untuk membangun kesadaran yang merupakan tujuan komunikator yaitu suatu perusahaan kepada penerima pesan atau kepada calon konsumen. Bentuk pengetahuan dan perhatian responden terhadap produk pariwisata Kabupaten Garut diukur melalui beberapa indikator, seperti memperhatikan postingan yang muncul di Home (beranda), profile picture yang digunakan, caption yang disajikan, dan hashtag yang disajikan oleh akun-akuninstagramproduk pariwisataKabupaten Garut. 
Berdasarkan hasil penelitian, sebanyak 100\% responden telah mencapai tahap attention. Sebanyak $54.7 \%$ responden memperhatikan profile picture yang digunakan oleh akunakun instagramproduk pariwisata Kabupaten Garut. Responden juga memperhatikan caption pada postingan, sebanyak $47.2 \%$ responden menjawab setuju.

Pada penggunaan hashtag juga responden cukup tinggi dalam memperhatikannya, yaitu sebanyak $41.5 \%$ responden. Indikator terakhir dalam attention adalah sebanyak $49.1 \%$ responden menjawab setuju bahwa responden memperhatikan postingan yang muncul di home atau berandanya.

\section{Interest (Ketertarikan)}

Interest merupakan tahapan ketertarikan followerssebagai responden atau telah lulus dari tahap kesadaran tentang produk tersebut. Setelah melalui tahapan attention biasanya followerstertarik lebih lanjut untuk mengetahui barang atau jasa yang ditawarkan. Informasi yang disampaikan menimbulkan perasaan ingin tahu lebih jauh sehingga konsumen mau melihat.Indikator yang digunakan untuk mengukur ketertarikan responden pada promosi yang dilakukan akun-akun produk pariwisata melalui instagram diantaranya adalah ketertarikan dengan melihat atau membaca postingan mengenai varian atraksi dan aktivitas, amenitas, aksesibilitas, harga produk, promosi produk, dan bentuk paket perjalanan. Pada tahap interest telah terjadi pengurangan responden sebanyak 4 responden karena hanya baru sampai dengan tahap attention sehingga total responden di tahap ini berjumlah 49 followers.

Berdasarkan hasil penilaian responden pada tahap interest, indikator ketertarikan melihat postingan untuk mengetahui berbagai varian produk wisata (alam, budaya, buatan) sebanyak $65.3 \%$ responden menjawab sangat setuju.Pada indikator membaca informasi yang terlampir pada postingan yang menyebabkan responden mengetahui berbagai varian produk wisata, sebanyak $59.2 \%$ responden menjawab sangat setuju.Indikator selanjutnya sebanyak $38.8 \%$ responden menjawab tidak setuju bahwa responden melihat postingan yang membuat responden mengetahui harga dan paket produk pariwisata yang ditawarkan.Hal serupa juga terjadi pada indikator membaca informasi yang terlampir menjadikan responden mengetahui harga dan paket produk pariwisata, sebanyak $40.8 \%$ responden menjawab tidak setuju.

Pada indikator lainnya pada tahap interest adalah sebanyak 51\% responden menyatakan sangat setuju bahwa setelah melihat postingan akun-akun instagram produk pariwisata Kabupaten Garut, responden yang dalam hal ini Generasi Z menjadi tahu akan fasilitas-fasilitas penunjang kegiatan wisata seperti akomodasi, restoran, moda transportasi yang akan digunakan. Indikator selanjutnya juga responden menjawab sangat setuju yaitu responden mengetahui informasi fasilitas penunjang wisata setelah membaca postingan yang ada, yaitu sebanyak $49 \%$ responden. Indikator terakhir pada tahap interest yaitu setelah melihat dan membaca postingan mengenai bentuk perhelatan (event) di 
Kabupaten Garut, responden sangat setuju menjadi tahu berbagai bentuk dari perhelatan (event) yang diselenggarakan oleh Kabupaten Garut.Hal ini terlihat sebanyak 55.1 \% responden menjawab setelah melihat menjadi tahu berbagai bentuk perhelatan.

\section{Desire (Keinginan)}

Desire merupakan keinginan untuk memiliki atau mengkonsumsi produk pariwisata yang ditawarkan setelah melihat akun-akun instagram produk pariwisata Kabupaten Garut.Followers akan mencari tahu lebih lanjut dengan produk yang ditawarkan, dapat dilihat dari feedback yang dilakukan followers dengan mengirim comment menanyakan informasi produk, untuk mengomentari postingan, memberi like pada postingan dan adanya rasa penasaran atau keinginan untuk membeli produk. Berikut Tabel berikut menggambarkan penilaian Generasi Z pada tahap desirem.

Tabel 10.

Prosentase Penilaian Generasi Z terhadap Akun Instagram Produk Pariwisata Kab. Garut pada Indikator-Indikator Desire

\begin{tabular}{clcccc}
\hline \multirow{2}{*}{ No } & \multicolumn{1}{c}{ Indikator } & \multicolumn{4}{c}{ Penilaian Responden } \\
\cline { 3 - 6 } & $\begin{array}{c}\text { Sangat Tidak } \\
\text { Setuju }\end{array}$ & Tidak Setuju & Setuju & Sangat Setuju \\
\hline 1 & $\begin{array}{l}\text { Mengirimkan comment } \\
\text { menanyakan informasi } \\
\text { produk }\end{array}$ & 6.5 & $\mathbf{3 2 . 6}$ & 30.4 & 30.4 \\
\hline $\begin{array}{l}\text { Mengirimkan comment } \\
\text { untuk mengomentari } \\
\text { postingan }\end{array}$ & 4.3 & 23.9 & $\mathbf{3 9 . 1}$ & 32.6 \\
\hline 3 & $\begin{array}{l}\text { Memberikan like pada } \\
\text { postingan }\end{array}$ & 2.2 & 2.2 & 41.3 & $\mathbf{5 4 . 3}$ \\
\hline 4 & $\begin{array}{l}\text { Pemasaran untuk membeli } \\
\text { produk }\end{array}$ & 2.2 & 2.2 & 45.7 & $\mathbf{5 0 . 0}$ \\
\hline
\end{tabular}

Sumber : Data Olahan, 2018

Berdasarkan hasil penilaian pada tahap desire sebanyak $32.6 \%$ responden menjawab tidak setuju bahwa responden memberikan comment untuk menanyakan informasi produk. Namun responden menjawab setuju bahwaresponden mengirimkan comment untuk mengomentari suatu postingan yang berada di akun-akunInstagram produk pariwisata Kabupaten Garut yaitu sebanyak 39.1 \% responden. Responden lebih tinggi dengan memberikan like pada postingan.Hal ini terlihat dari jumlah responden Generasi $\mathrm{Z}$ yang menjawab sangat setuju pada indikator memberikan like dengan jumlah setengah dari jumlah responden yang mencapai tahap desire yaitu sebesar 54.3\% responden. Pada indikator terakhir di tahap desire yaitu sebanyak 50\% responden menjawab sangat setuju bahwa responden Generasi $\mathrm{Z}$ memiliki keinginan dan penasaran untuk melakukan kegiatan wisata di Kabupaten Garut. 


\section{Action (Tindakan)}

Action merupakan tahapan terakhir dalam mengukur efektivitas media promosi produk pariwisata melalui akun-akun instagram produk pariwisata Kabupaten Garut, yaitu merupakan tindakan melakukan pembelian oleh responden terhadap suatu produk. Pelaku bisnis memiliki tujuan untuk mendorong calon konsumen untuk melakukan tindakan setelah melalui tahap-tahap sebelumnya, tindakan yang diharapkan adalah mendorong calon konsumen untuk membeli produk. Apabila konsumen puas dengan produk yang dibeli, maka akan terjadi pembelian ulang atau pembelian kembali produk yang ditawarkan. Tidak hanya tindakan membeli, tetapi tindakan setelah melakukan pembelian termasuk kedalam kategori tahapan action.

Terdapat lima indikator yang menggambarkan tahapan action, yaitu berupa pembelian produk pariwisata alam, budaya dan buatan di Kabupaten Garut, merekomendasikan teman atau kerabat untuk membeli produk, melakukan testimoni pembelian produk ke akun media sosial, dan memposting foto atau video atau status pada akun media sosial yang dimiliki oleh responden setelah melakukan pembelian.

Tabel 11.

Prosentase Penilaian Generasi $\mathbf{Z}$ terhadap Akun Instagram Produk Pariwisata Kab. Garut pada Indikator Action

\begin{tabular}{clcccc}
\hline \multirow{2}{*}{ No } & \multicolumn{1}{c}{ Indikator } & \multicolumn{4}{c}{ Penilaian Responden } \\
\cline { 3 - 6 } & $\begin{array}{c}\text { Sangat Tidak } \\
\text { Setuju }\end{array}$ & $\begin{array}{c}\text { Tidak } \\
\text { Setuju }\end{array}$ & Setuju & $\begin{array}{c}\text { Sangat } \\
\text { Setuju }\end{array}$ \\
\hline 2 & Melakukan kegiatan wisata & 2.2 & 0 & 26.7 & $\mathbf{7 1 . 1}$ \\
\hline 3 & $\begin{array}{l}\text { Mengajak teman untuk } \\
\text { melakukan kegiatan wisata }\end{array}$ & 0 & 8.9 & 33.3 & $\mathbf{5 7 . 8}$ \\
\hline 4 & $\begin{array}{l}\text { Mengajak kerabat untuk } \\
\text { melakukan kegiatan wisata }\end{array}$ & 2.2 & 8.9 & 31.1 & $\mathbf{5 7 . 8}$ \\
\hline 5 & $\begin{array}{l}\text { Mengirim komentar berisi } \\
\text { testimony }\end{array}$ & 4.4 & 22.2 & $\mathbf{4 8 . 9}$ & 24.4 \\
\hline
\end{tabular}

Sumber : Data Olahan, 2018

Berdasarkan Tabel 11 diatas terlihat bahwa responden yang mencapai tahap action melakukan pembelian terhadap produk wisata sebesar $71.1 \%$ responden.Responden yang merekomendasikan kepada teman maupun kerabat yaitu sebanyak 57.8\%.Responden juga melakukan tahapan action dengan mengirim komentar berisi testimoni setelah melakukan kegiatan wisata dengan menjawab setuju pada indikator tersebut sebesar $48.9 \%$ responden.Sedangkan pada indikator terakhir sebesar $40 \%$ responden menjawab sangat setuju telah melakukan postingan di seluruh akun media sosial. 


\section{SIMPULAN}

Berdasarkan hasil analisis yang telah dilakukan untuk menggali tentang media sosial sebagai sarana informasi dan promosi yang diperuntukkan bagi kaum generasi Z, maka dapat dihasilkan kesimpulan sebagai berikut:

1. Secara umum wisatawan yang berkunjung ke Kabupaten Garut dalam penelitian ini disasar pada generasi $\mathrm{Z}$ memiliki rentangan usia rata-rata 22 tahun dengan gender wanita yang paling banyak yaitu sebesar $73.6 \%$ sedangkan untuk gender laki-laki sebesar $26.4 \%$. Dari banyaknya generasi $\mathrm{Z}$ yang berkunjung sebanyak $49.05 \%$ merupakan pelajar tingkat menengah atas, ini membuktikan bahwa Kabupaten Garut menjadi destinasi wisata yang favorit bagi kalangan pelajar ini dikarenakan jaraknya yang tidak terlalu jauh dari ibu kota provinsi Jawa Barat sehingga dana yang dikeluarkan oleh pelajar masih bisa terjangkau. Generasi $Z$ yang memiliki rentangan usia 22 tahun sampai dengan 24 tahun dan sudah memiliki pekerjaan memiliki interval pendapatan sebesar 500.000 sampai dengan 1.000.000 ini membuktikan sekali lagi bahwa Kabupaten Garut dianggap destinasi wisata yang relatif terjangkau dan mampu untuk dinikmati oleh kaum muda atau yang dikenal dengan generasi $\mathrm{Z}$.

2. Keterdedahan dalam memilih media sosial bagi wisatawangenerasi Zdi Kabupaten Garut perlu untuk ditelusuri guna peningkatan efektivitas komunikasi dalam penyampaian informasi dan promosi destinasi wisata. Penelusuran efektivitas komunikasi dalam penelitian ini dengan menggunakan AIDA (Attention, Interest, Desire, Action). Dari hasil penelitian ini pengukuran frekuensi pesan dengan kategori tinggi mencapai nilai sebesar $77.4 \%$. Sosial media yang digemari oleh generasi Z yang berkunjung ke Kabupaten Garut adalah Instagram dengan kualitas tingkat foto atau video yang bagus tentang destinasi wisata Kabupaten Garut, sehingga pencarian akan informasi destinasi wisata khususnya di Kabupaten Garut bagi generasi Z didasarkan pada visualisai.

3. Tingkat efektivitas promosi akan media sosial Instagram pada penelitian ini dengan pengukuran menggunakan pendekatan AIDA dapat diuraikan sebagai berikut :

(a) Attention, berdasarkan dari hasil penelitian untuk tingkat attention didapat bahwa $100 \%$ generasi $\mathrm{Z}$ tertarik dan mencari informasi tentang destinasi wisata Kabupaten Garut dengan browsing melalui sosial media Instagram.

(b) Interest, dalam hal ketertarikan berrbanding lurus dengan Attention dengan presentase yang cenderung tinggi yaitu bernilai $92.45 \%$. Para generasi Z tertarik akan foto atau video yang diunggah oleh akun-akun promosi destinasi wisata Kabupaten Garut.

(c) Desire, dari ketertarikan yang dilihat secara visual dari Instagram dapat menimbulkan keinginan untuk berkunjung, dan tingkat presentasenya sebesar 
$86.79 \%$. Kabupaten Garut dianggap sebagai pijakan destinasi wisata pertama bagi generasi $\mathrm{Z}$ untuk memulai kegiatan wisata sebelum berkunjung ke tempat yang lebih jauh lagi.

(d) Action, keinginan untuk berkunjung ke destinasi wisata Kabupaten Garut sebesar $84.9 \%$ direalisasikan menjadi action atau kunjungan nyata ke Kabupaten Garut. Generasi Z yang telah berkeinginan untuk berkunjung ke Kabupaten Garut lebih dari $50 \%$ akan merealisasikan kunjungannya, dan kunjungan itu dapat berupa grup atau pun family (bersama keluarga).

Dalam penelitian ini ditemukan juga bahwa generasi Z yang melakukan kunjungan wisata ke Kabupaten Garut menginginkan adanya aplikasi online dengan tujuan untuk memudahkan kegiatan wisata, maka peneliti mengusulkan selain dibuatnya account resmi Instagram tentang wisata Garut dibuatkan juga aplikasi mobile berisi tentang directory destinasi wisata Garut, jadwal event, atau pun tentang akses ke destinasi wisata tertentu di Kabupaten Garut untuk memudahkan itenarary kunjungan bagi para generasi Z. Berikut ditampilkan aplikasi secara sederhana untuk mengakomodir kebutuhan generasi Z :

\section{Gambar 3. Model Aplikasi Kabupaten Garut 2017}
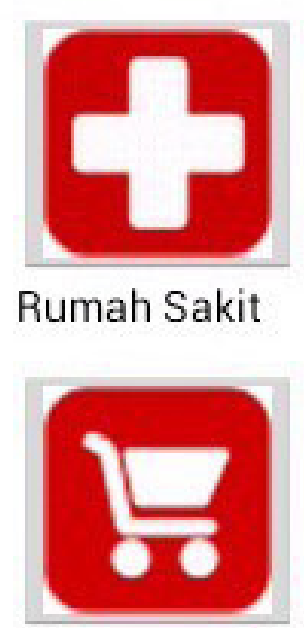

Mini Market

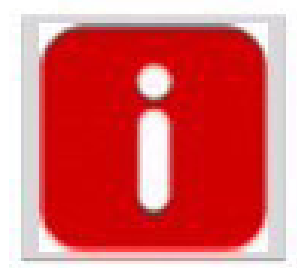

About

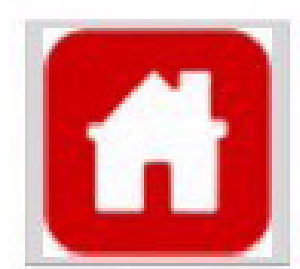

Hotel
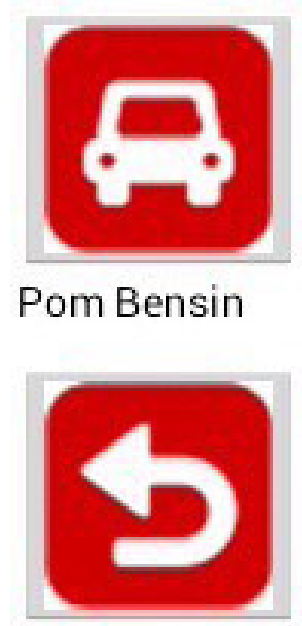

Exit

Gambar 3 diatas merupakan aplikasi sederhana yang dapat dibuat dengan adroid basis.Aplikasi tersebut dapat ditambah dengan directory destinasi wisata dan jadwal event Kabupaten Garut. 


\section{DAFTAR PUSTAKA}

https://tirto.id/selamat-tinggal-generasi-milenial-selamat-datang-generasi-z-cnzX

Kurniawati, Novi. 2017. Pemanfaatan Instagram Oleh Komunitas Wisata Grobogan dalam Mempromosikan Potensi Pariwisata Daerah. Jurnal Universitas Muhammadiyah Surakarta. (online), 2943-7984-1-PB. 2017.

Kotler, Philip., dan Gary Armstrong. 2004. Dasar-Dasar Pemasaran. Edisi kesembilan, Jilid 2, dialihbahasakan oleh Alexander Sindoro, Jakarta: Indeks.

Kotler, Philip, dan Gary Armstrong. 2012. Prinsip-Prinsip Pemasaran. Edisi ketigabelas, Jilid 1. Jakarta:Erlangga.

Nrayung R. 2012. Perilaku Pemanfaatan Situs Jejaring Sosial (Facebook) di SMAN 2 Surabaya. [skripsi]. [internet]. [diunduh tanggal 20 Juni 2016]. Dapat diunduh di: http://journal.unair.ac.id/download-fullpapers-jurnal- riajeng.doc

Rangkuti, Freddy., 2010. Analisis SWOT Teknik Membedah Kasus Bisnis. PT. Gramedia Pustaka Utama : Jakarta.

Salamoon DK. 2013. Instagram, Ketika Foto Menjadi Mediator Komunikasi Lintas Budaya di Dunia Maya [skripsi]. [internet]. [diunduh tanggal 20 Januari 2016]. http://repository.petra.ac.id/16642/1/Publikasi1_10021_1481.pdf

Samsi SN. 2005. Hubungan keterdedahan siaran iklan produk susu balita di televisi dengan keputusan pembelian (kasus ibu rumah tangga di perumahan Villa Bogor Indah).[Skripsi]. Bogor (ID): Institut Pertanian Bogor. 98 hal.

Sumarwan U. 2011. Perilaku Konsumen: Teori dan Penerapannya dalam Pemasaran Bogor [ID]: Ghalia Indonesia.

Sumarwan U. 2004. Perilaku Konsumen: Teori dan Penerapannya dalam Pemasaran. Bogor [ID]: Ghalia Indonesia.

Wulandari YS. 2015. Efektivitas promosi melalui twitter pada perusahaan pariwisata bahari “ibu penyu”. [skripsi]. Bogor (ID): Institut Pertanian Bogor. 